\title{
Light dazzles from the black box: whole-cell biosensors are ready to inform on fundamental soil biological processes
}

\author{
Giancarlo Renella* and Laura Giagnoni
}

\begin{abstract}
Whole-cell biosensors are natural or engineered microorganisms producing signals in response to specific stimuli. This review introduces the use of whole-cell biosensors for the study of the soil system, discuss the recent developments and some current limitations and draws future prospects of the whole-cell biosensors for application to the study of the agro-ecosystems. The review focuses mainly on the lux- and gfp-inserted whole-cell biosensors producing bioluminescence and multicoloured fluorescent proteins, which allow an easy and reproducible detection of the signals from a large number of prokaryotic and eukaryotic soil-borne microorganisms. This review also points out how the whole-cell biosensors indicate the bioavailability of selected analyte, an information that cannot be straight forwardly extrapolated using the chemical methods of soil analysis. However, regardless of the immense progress in biotechnology and genetics that allows to construct whole-cell biosensors for virtually detecting any chemical at ultra low concentrations, the soil still remains the most extreme natural system to be studied with these biotechnological analytical tools. Although a lack of standardization for most of the constructed whole-cell biosensors along with the scarce knowledge of their performance concur to prevent their use in the official methods of soil and environmental analysis, owing to their stability and selectivity we restate that the whole-cell biosensors are ready to provide information on the main processes occurring in soil, and represent unprecedented sensitive tools for improving agriculture and for soil monitoring.
\end{abstract}

Keywords: Whole-cell biosensors, Soil and environmental analysis, Nutrient and contaminant bioavailability, Ecological interactions in soil, Future agriculture

\section{Introduction}

Understanding of how microorganisms actually perceive the surrounding soil habitat and how they react to changes of environmental conditions is a great challenge to soil scientists and microbial ecologists, and is considered a need for the optimal management and conservation of soil microflora and microbially driven key soil functions. As a reactor, soil has been classically seen as a black box [59] capable of degrading and transforming all known chemical compounds, in accordance with the microbial metabolic infallibility dictum [1]. This view was consolidated by the outcome of experiments based on the

*Correspondence: giancarlo.renella@unifi.it

Department of Agrifood Production and Environmental Sciences,

University of Florence, P.le delle Cascine 18, 50144 Florence, Italy soil inoculation with organic substrates and inhibitors, or by exposing soils to varied moisture and temperature conditions followed by the analysis of the substrate use, products release or changes in the soil microbial communities. However, this approach does not provide information on the metabolic pathways active within microbial cells. The soil black box has been partially opened from the 1990s through the quantification of microbial C, N, $\mathrm{P}$ and S microbial pools from the 1970-1980s [16], and the characterization of the soil microbial communities by genomics [126], proteomics [37], transcriptomic [64], metabolomic [121] and lipidomic [21]. However, there is a general consensus on the idea that the knowledge on microbial diversity and the rate of soil functions still do not allow to understand the factors leading to gene expression in the microbial communities, and that this 
gap prevents the development of an ecological theory of the soil environment. The scope of this review is to illustrate how the biosensors can reveal the mechanisms leading to gene expression in the complex soil matrix, hold potentials to optimize the crop nutrient use efficiency and provide new tools in the study of plant-microbe interactions. The final goal is to fuel the use of the wholecell biosensors as a new paradigm in soil and agricultural sciences. Detailed description of the genetic construction whole-cell biosensor and signal detection systems are out of the scopes of the present review, and we refer to previous comprehensive reviews $[8,39,42,66,71,83,84,130$, 131, 134].

\section{Biosensors types and functioning}

Whole-cell biosensors should be distinguished from the chemical sensors that, according to IUPAC, are devices in which the recognition system is a natural or engineered biological molecule reacting with a biochemical mechanism producing a detectable physical or chemical signal, linked to a device for signal transduction. The IUPAC further classifies the biosensors according to the biological specificity, mode of signal transduction and on the variation (consumption/production) of analyte concentration. This type of biosensors are not discussed in the present review, and readers interested in the potential of chemical biosensors are referred to the IUPAC Gold Book [57], and specifically for soil applications to the comprehensive review by [97]. Chemical and cellular biosensors share the common recognition mechanisms, but for whole-cell biosensor recognition of a selected analyte occurs after its transport across the cell membrane and diffusion within the intracellular components, and hereafter will be termed biosensors.

Biosensors are either natural or engineered microorganisms, typically bacteria, producing a detectable signal encoded by a reporter gene, upon activation of a promoter gene induced by specific stimuli. Depending on the regulation of the promoter gene expression mechanism, biosensors can be classified as constitutive or inducible. The use of reporter genes for detecting the factors triggering genetic responses in living organisms dates back to the 1940s, when Monod [87] and Novick and Weiner [91] first described the functioning of the lac operon (the lacZ coding for the $\beta$-galactosidase enzyme) and its relation with microbial growth patterns. These seminal studies have been confirmed after the discovery of the biological role and structure of DNA, and other reporter genes such as, $x y l \mathrm{E}$ (coding for the catechol-2,3-dioxygenase) and $t f d \mathrm{~A}$ (coding for the 2,4-dichlorophenoxyacetate oxidase) have been widely used as biophysical model for understanding the microbial sensing of specific analyte in their environment [35]. However, these early reporter genes are not useful for studying the metabolic activity of soil microorganisms because their products cannot be resolved against the strong background of these enzymes in soil. Differently, signals such as bioluminescence or fluorescent proteins can be easily and sensitively detected in soil.

Biosensors can be naturally or genetically modified microorganisms emitting luminescence or fluorescence constitutively or linked to the expression of specific functional genes. Because the signal intensity is related to the level of the cellular metabolism or the activation of specific promoters, luminescent and fluorescent microorganism have been increasingly used to gain indications of biological responses to changes in a complex and heterogeneous natural matrix as soil (Fig. 1).

\section{Biosensors for environmental analysis}

The first lux-constructs concerned enteric bacteria such as Escherichia coli and Salmonella tyyphimurium, well characterized from the genetic point of view, but these biosensors are of limited relevance to the study of soil and environment as they are likely affected by soil constituents. In the last two decades, a wide range of whole-cell biosensors based on lux-constructs of soilborne bacteria for detecting organic and inorganic pollutants and monitoring nutrient availability in soil have been constructed (Table 1). Biosensors in which luxor $g f p$-inserted reporter genes are under control of an inducible promoter that can be used to detect the bioavailability of specific analyte. In this case a metabolic regulatory pathway is fused with a promoterless gene coding for easily measurable protein products. Typically, the activation of the promoter is induced when the analyte binds the repressor, acting as the selective bioreceptor for the analyte, or through complex cellular events that lead to the expression of the reporter gene. Inducible biosensors are of great interest for modern soil and agricultural sciences because development in molecular techniques makes it possible to virtually insert reporter genes under the control of any chromosomal or plasmidial promoter, making the constructed strains capable of detecting different analyte with high specificity [44]. Genetic engineering of soil-borne bacteria ensures the minimization of potentially interfering soil factors. Advances in microelectronics have allowed the use of riboswitches and reporter genes based on forster resonance energy transfer (FRET) for the detection of the expression of fluorescent proteins after exposure to selected analyte. A list of promoter-reporter genes used for construction of whole-cell biosensors successfully tested in soil and environmental studies is reported in Table 1. 


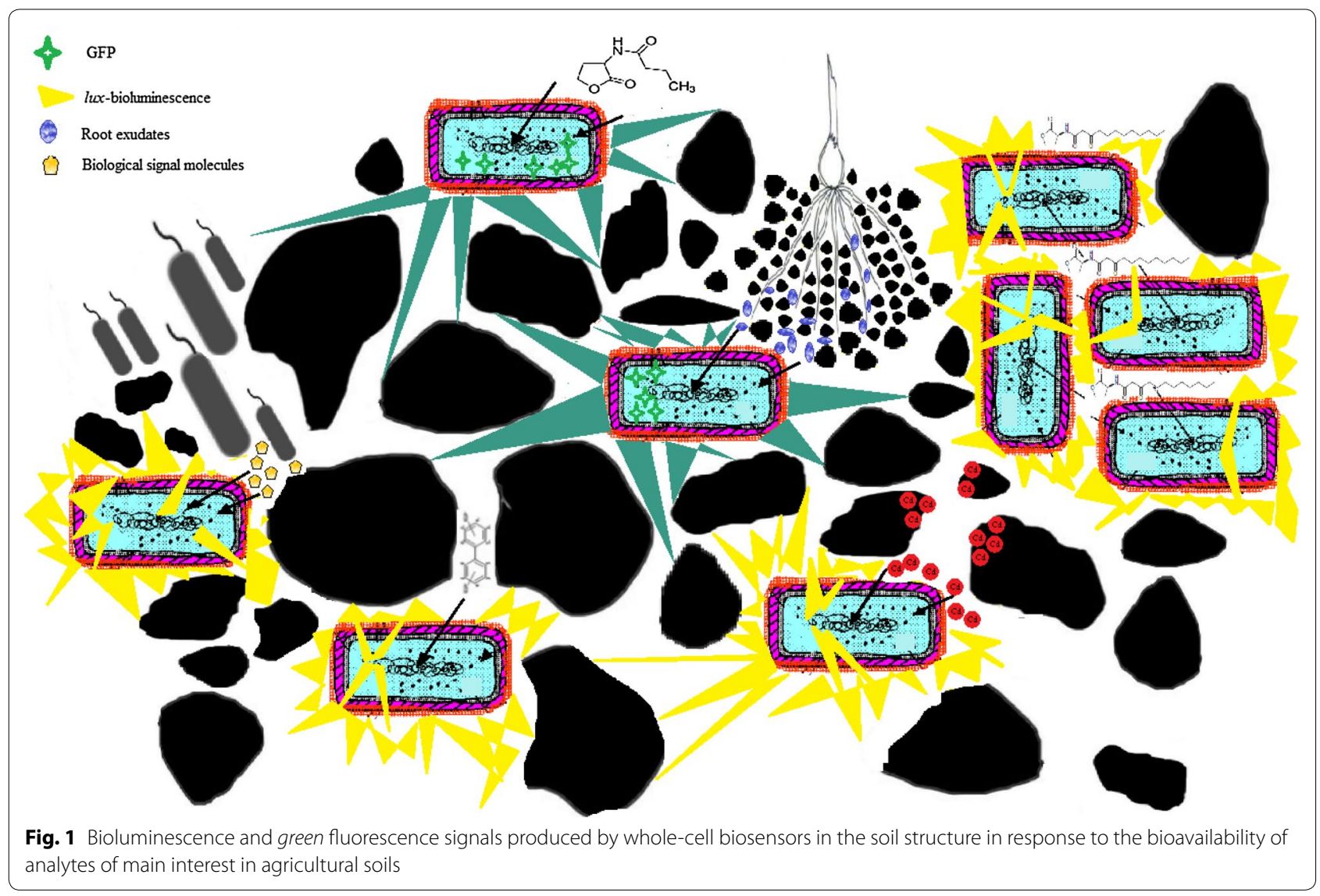

\section{Applications of biosensors to soil and environmental studies}

Early environmental applications of biosensors employed naturally luminescent $(490 \mathrm{~nm})$ bacteria such as Vibrio fischeri (re-classified as Alivibrio fischeri) for monitoring water quality [18], sediments and pore water toxicity [17, 31], waste toxicity [122] and efficiency of bioremedation [137]. Several biosensor-based systems based on Vibrio fischeri as reporter strain have been commercialized such as Microtox ${ }^{\circledR}$ (Modern Water, UK), BioTox ${ }^{\circledR}$, LUMIStox ${ }^{\circledR}$ (Hach Lange, Germany), TOXmini ${ }^{\circledR}$ (microLAN, The Netherlands) or ToxAlert ${ }^{\circledR}$ (Merck, Germany) and iTOX control $^{\circledR}$ (microLAN, The Netherlands), BIOMET ${ }^{\circledR}$ and VITOTOX $^{\circledR}$ (GENTAUR, Belgium) [18, 46, 52, 60, 69, 129]. These constitutive naturally luminescent biosensors provide information on the soil and environmental toxicity because the luciferase activity is related to cell integrity and full metabolic activity and is reduced upon cell damage or toxicity. A standard protocol for bioluminescence-based environmental toxicity assessment has been set up (ISO 11348 2007) and successfully used for the analysis of toxicity of polluted and remediated soils e.g. [7]. Two naturally bioluminescent fungi, Armillaria mellea and Mycena citricolor have been also used to assess the toxicity to microeucaryotes [139]. However, these biosensor types provide general information on the cell integrity but not on the response of specific genes to the presence of specific analyte.

\section{Genetically modified biosensors}

The soil-borne bacteria with the promoterless $l u x \mathrm{CD}$ $\mathrm{ABE}$ gene cassette inserted in transcriptional fusion with the promoter genes of operons inducible by naphthalene and its metabolite salicylate were Pseudomonas fluorescens HK44 and P. putida RB1353 [19, 55]. This pioneer work demonstrated that a regulatory genetic circuit could be artificially fused with an exogenous luciferase gene producing a bioluminescence signal upon exposure or uptake of specific analyte by the host cell, and opened the road to the construction of several and more analyte-specific whole-cell biosensors whose responses can be calibrated, and interpreted as microbial genetic responses to environmental stimuli. Further improvement of the original insertion scheme led to the set up of a large number of whole-cell biosensors in which the promoterless $l u x$ and $g f p$ genes are fused under control of inducible promoters producing bioluminescence or fluorescence. A sample of whole-cell 
Table 1 Strains and plasmids (in brackets) used for constructing whole-cell biosensors inserting lux, gfp and $\beta$-galactosidase reporter genes responding to different organic and inorganic compounds and elements

\begin{tabular}{|c|c|c|c|}
\hline Whole-cell biosensor & Signal & Target analyte & Reference \\
\hline \multicolumn{4}{|l|}{ Organic xenobiotics } \\
\hline P. fluorescens HK44 (pUTK21) & Bioluminescence & Naphtalene & {$[55]$} \\
\hline P. putida RB1353/RB1351 (pUTK9) & Bioluminescence & BTEX & {$[19]$} \\
\hline P. putida RB1401 (pTOL) & Bioluminescence & BTEX & {$[20]$} \\
\hline P. putida TVA8 (pUTK214) & Bioluminescence & BTEX & {$[6]$} \\
\hline Stenotrophomonas sp ENV307 (pUTK60) & Bioluminescence & Alkylsulphonates & {$[73]$} \\
\hline R. eutropha JMP134 (pUTK220) & Green fluorescence & PCB & {$[49]$} \\
\hline Burkholderia sp (pUCD607) & Bioluminescence & PCB & {$[15]$} \\
\hline Pseudomonas putida F1 (pUT mini-Tn5 luxCDABE) & Bioluminescence & PCB & [138] \\
\hline N. europaea ATCC 19718(pHLUX20) & Bioluminescence & Alkylsulphonates & {$[11]$} \\
\hline P. fluorescens A506 (pTS) & Green fluorescence & BTEX & [120] \\
\hline \multicolumn{4}{|l|}{ Heavy metals and metalloids } \\
\hline S. aureus RN4420 (pl258) & Bioluminescence & As & {$[24]$} \\
\hline C. metallidurans CH34 (pMOL30) & Bioluminescence & $\mathrm{Cd}, \mathrm{Zn}, \mathrm{Ni}$ & {$[23]$} \\
\hline R. leguminosarum bv trifolii F6 (pUCD607) & Bioluminescence & $\mathrm{Cu}$ & {$[96]$} \\
\hline C. metallidurans AE1239 (pMOL30) & Bioluminescence & $\mathrm{Cr}$ & {$[25]$} \\
\hline P. putida KT2440 (pUT-mer-lux) & Bioluminescence & $\mathrm{Cu}$ & {$[43]$} \\
\hline \multicolumn{4}{|l|}{ Nutrients and physiologically active molecules } \\
\hline P. fluorescens 10586 (pP2) & Bioluminescence & C & {$[67]$} \\
\hline P. fluorescens DF57 N3 (pP2) & Bioluminescence & $\mathrm{N}$ & {$[67]$} \\
\hline P. fluorescens DF57 P9 (pP2) & Bioluminescence & $P$ & {$[67]$} \\
\hline P. putida KT2440 (pLYS24-davT-lux) & Bioluminescence & C & {$[34]$} \\
\hline P. fluorescens WCS365 (pMP5291) & Bioluminescence & Putrescine & {$[68]$} \\
\hline R. leguminosarum 4292 (plJ1737) (plJ1730) & $\beta$-galactosidase & Nodulation factors & [9] \\
\hline R. leguminosarum 3841 (pOT1) & Green fluorescence & Nodulation factors & {$[2]$} \\
\hline P. fluorescens F113 SF3 (pLS312), SF5 (pLS52) & Bioluminescence & Ecological interactions & {$[117]$} \\
\hline
\end{tabular}

$B T E X$ benzene, toluene, ethylbenzene and xylene; $P C B$ polychlorinated biphenyls; $A$ s arsenic; $C d$ cadmium; $C r$ chromium, $C u$ copper; $C$ carbon, $N$ nitrogen; $P$ phosphorus

biosensors constructed on soil-borne bacteria is reported in Table 1.

Eukaryotic biosensors are based on $l u x-$, luc- and $g f p$ inserted yeasts, microalgae and protozoa (for a review, see [42]). However, while microalgae and yeast-based biosensors have been mainly used for studying metal availability in water bodies and other environmental matrices, protozoa biosensors such as Tetrahymena thermophila inserted with the luc or $g f p$ genes in transcriptional fusion with metallothionein genes inducible upon exposure to $\mathrm{Cd}$ and $\mathrm{Pb}$ showed promising applications [3, $4]$.

\section{Indication of bioavailability: the edge over soil chemical analysis}

The most important feature of biosensors in soil and environmental studies is that they can indicate the bioavailability, which is the crossing of the cell membrane by selected analyte triggering a genetic of a genetic response. Currently, this information cannot be obtained by soil chemical analyses, and can only be indirectly inferred by studies on the genomic and proteomic responses of soil organisms [108]; in fact effects of nutrient or pollutant availability to soil microbial communities can be estimated from the induced permanent changes in the structure and diversity of the soil microbial communities.

Chemical characterization of bioavailability in soils is based on the assumption that it mainly depends on sorption/desorption processes that regulate the elemental concentrations in the soil solution from where plants and soil organisms perform the absorption process [98], and it has been demonstrated that the elemental absorption by plants is generally correlated to specific chemical pools [53], whereas the elemental availability to soil microorganisms is more difficult to be assessed by chemical methods [48]. Differently, the measurement of biosensor responses to specific analyte in soil may allow an online monitoring of the elemental bioavailability by monitoring the induction of specific promoters, allowing a better assessment of bioaccumulation and biomagnification 
in food chains, and therefore improving the risk assessment for terrestrial ecosystems. Although the toxicity of a specific compound or element can vary for different organisms, it has been reported that the median effective concentrations $\left(\mathrm{EC}_{50}\right)$ of more than 1200 chemical substances for prokaryotes, eukaryotes and humans can be compared to their effects on $V$. fischeri bioluminescence [101].

\section{Biosensors for agricultural management and soil monitoring}

\section{Biosensors for assessing nutrient availability}

Plant uptake of nutrients occur in the rhizosphere which is the soil portion physically and chemically modified by the release of root exudates, and where potential competition for nutrients between plants and microorganisms takes place. Nutrient availability in rhizosphere and bulk soil be studied with the $l u x$-inserted strains of $P$. fluorescens strains expressing bioluminescence under $\mathrm{C}, \mathrm{N}$ and $\mathrm{P}$ and starvation conditions and proportionally reduce their bioluminescence upon the assimilation of the nutrients $[67,109]$. These biosensors have been successfully used to estimate the nutrient availability in various soils and during the decomposition of the organic matter $[34,61]$, and to evaluate the nutrient flow in the rhizosphere [141]. Protocols for simultaneous determinations of $\mathrm{C}, \mathrm{N}$ and $\mathrm{P}$ availability using the P. fluorescens strains 10586 pUCD607, DF57 N3 and DF57 P9 have been set up by Standing et al. [118]. Using the luminescent cellular biosensor P. fluorescens 10586 pUCD607 [27] monitored the release of root exudates in response to $\mathrm{NO}_{3}{ }^{-}-\mathrm{N}$, and demonstrated that lowering of nitrate concentrations in the rhizosphere induced an increase of the rhizodepositions by Hordeum vulgare at the root apex. The nutrient assimilation in soil has been also studied with GFP-expressing biosensors under the control of the promoter of the operon narG in E. cloacae EcCT501R [56] and inaZ of P. syringae expressing the ice nucleation protein in response to increased intracellular concentrations of the $\mathrm{NO}_{3}{ }^{-} \mathrm{N}$. Using these biosensors DeAngelis et al. [28] demonstrated that the $\mathrm{NO}_{3}{ }^{-}$availability increased in the rhizosphere of Avena fatua as compared to bulk soils and that nitrate fertilization could reduce the root/microbe competition for $\mathrm{NO}_{3}{ }^{-} \mathrm{N}$. It was also shown that $\mathrm{N}$ becomes limiting during the organic matter decomposition for soil microorganisms. Assimilation of orthophosphate by microorganisms has been monitored by the use of FRET biosensors on Synechococcus strains by engineering the genes encoding for the phosphate-binding protein [41]. However, it should be underlined that $\mathrm{N}$ and $\mathrm{P}$ limitation in the rhizosphere could depend not only on their total concentrations but also on their chemical forms and speciation. For example, the lux-based Pseudomonas N-reporter strains reporting $\mathrm{N}$ limitation also reacts to the exposure to aminoacids such as glutamate or lysine, like in the case of the $P$. putida that responds to lysine in the rhizosphere or bulk soil of oat plants [34]. Jaeger et al. [58] detected the presence of tryptophan and sucrose from the mature districts of lateral roots and sucrose to the root apex, respectively, using an Erwinia herbicola biosensor with the inaZ under control of a tryptophan-inducible gene. Using a $P$. fluorescens biosensor, in which the lux gene was under control of the promoter of rDNA synthesis, Marschner and Crowley [82] demonstrated that the release of root exudates sustained the higher cellular activity of $P$. fluorescens in the plant rhizosphere than in bulk soil. Ramos et al. [104] using a P. putida strain encoding an unstable GFP variant for $g f p$ genes under control of rDNA promoters showed that active rhizobacteria were preferentially localized at the root apex as compared to the mature or senescent root districts.

\section{Biosensors for assessing bioavailability of heavy metals and metalloids}

Soils have high retention capacity to soil towards inorganic and organic pollutants due to their content of highly reactive inorganic and organic phases. Biosensors have been extensively used for studying the bioavailability of heavy metals and metalloids in polluted soils, mainly using $l u x$ and $g f p$ reporter genes inserted under promoters responding to increased intracellular metal concentrations [78]. Gram-positive and gram-negative bacteria resist to $\mathrm{Hg}$ through reduction of $\mathrm{Hg}^{2+}$ into its elemental form and volatilization through enzymes coded by the mer operon found on either chromosome, plasmids or transposons [86]. The knowledge of the mer operon regulation has allowed the construction of $l u x$-inserted biosensors by inserting the luxCDABE cassette in the Pmer promoter of the merTPC genes [112], through insertion of the regulatory merR gene with the reporter $l u c$ gene in the E. coli MC1061 [135] or a luxCDABE construct of Pmer in P. putida KT2440 [43], with in vitro detection limits in the order of $0.1 \mathrm{fM}$. An E. coli-based biosensor was constructed by Ramanathan et al. [103] inserting the ars $\mathrm{R}$ regulatory gene upstream of a promoterless lux $\mathrm{AB}$ gene in a plasmidial ars operon, which can detect As without effects of other oxyanions such as phosphate, sulphate or nitrate. In C. metallidurans CH34 (formerly Ralstonia metallidurans), carrying genes encoding inducible multiple metal resistance on the plasmid pMOL28, allowed the construction of a Cr-responding biosensor [25] a chr-lux fusion (strain AE104 pEBZ141) that responded to both $\mathrm{Cr}(\mathrm{III})$ and $\mathrm{Cr}(\mathrm{VI})$, with $\mathrm{Cr}(\mathrm{VI})$ producing a 10-fold signal as compared to $\mathrm{Cr}$ (III). A biosensor responding to $\mathrm{Cr}$ based on $\mathrm{O}$. tritici sensitive 
expressing the $g f p$ gene under the control of the chr promoter and the $c h r \mathrm{~B}$ regulator [10]. Biosensors for detecting $\mathrm{Cd}, \mathrm{Zn}, \mathrm{Cu}, \mathrm{Pb}$ and other cationic trace elements have been created inserting reporter genes in genetic sequences encoding multiple resistance mechanisms of different microorganisms, such as P-type ATPase efflux pumps or multicomponent efflux mechanisms encoded by structural (e.g. cadA) and regulator (e.g. cadC) plasmidial genes or operons (Nies [90]). A Bacillus subtilis BR151 biosensor, carrying the pTOO24 plasmid inserted with the luc gene under transcriptional control of $c a d C$ of the cad operon was proposed by Tauriainen et al. [123]. More metal-specific biosensors were constructed in $E$. coli inserting the $\operatorname{lux} \mathrm{AB}$ in the promoters of genes conferring resistance through P-type ATPases [24] or using the regulatory mechanisms of the cop, $p b r, c z c$ operons induced by $\mathrm{Cu}, \mathrm{Pb}$ or $\mathrm{Cd}$, respectively, present on plasmids or megaplasmids of $C$. metallidurans and fused with the promoterless lux CDABE [25]. A bioluminescent $\mathrm{Cu}$-specific biosensor was constructed in P. fluorescens by Tom-Petersen et al. [125]. Using a constitutive $\mathrm{Cu}$-sensitive P. fluorescence strain Maderova et al. [77] showed that $\mathrm{Cu}$ bioavailability was different depending on the $\mathrm{Cu}$ source and that, although the responses were correlated to free $\mathrm{Cu}^{2+}$ concentrations it also indicated the bioavailability of other $\mathrm{Cu}$ forms, and the same was observed for $\mathrm{Zn}$ [76], confirming the previous finding by Brandt et al. [12], that dissolved organic matter can increase the metal bioavailability in soil.

\section{Biosensors for assessing bioavailability of organic pollutants}

Hydrophobic organic compounds once released into soil become less available due to sorption and exhibit declined toxicity with time. Typically, the sorbed compounds become less accessible upon time and are therefore considered unavailable [54]. However, accumulation of organic pollutants in soils pose significant risks to human health and ecosystems [115], and there is still a large uncertainty on the best protocols for estimating their bioavailability in soil [113]. A large number of biosensors is also available for detection of either natural organic substances or organic pollutants, potentially very useful for characterization of risks posed by contaminated soils. Alkanes and derivatives can be detected using biosensors developed by inserting the alk regulon of Pseudomonas oleovorans, with the lux $\mathrm{AB}$ genes from $V$. harveyi, and the constructed plasmid transformed in E. coli DH5R which becomes bioluminescent specifically when exposed to linear alkanes, whereas biosensors for linear alkylsulphonates based on Nitrosomonas europaea [11] or Stenotrophomonas and Ralstonia strains [73] have been constructed by $\operatorname{lux} \mathrm{AB}$ gene fusion with catabolic genes. Biosensors responding to bioavailable benzene, toluene and xylene (BTEX) in soil have been constructed by inserting the luxCDBAE or luc genes (lucFF is the firefly Photinus pyralis luciferase gene) in different plasmidial genes involved in the catabolic pathways of such compounds, using P. putida strains [6, 20] or E. coli [140]. Insertions of different reporter genes improve the sensitivity towards specific BTEX compounds because their degradation to pyruvate or acetaldehyde is controlled by several intermediate metabolites and enzymes. Sensitive $g f p$-based biosensors for the detection of toluene and benzene have been constructed by Stiner and Halvorsen [120] and Casavant et al. [22], inserting different plasmidial genes in P. fluorescent strains, and biosensor more specifically responding to benzene has been constructed by Di Gennaro et al. [30], and a comparative study on the $l u x$ - and $g f p$-based biosensors for the detection of toluene and related compounds in polluted soils was performed by Li et al. [65].

Biosensors for detection of chlorinated and organic polychlorinated pollutants are based on a P. fluorescens 10,586s, Burkholderia sp. Rasc strain with lux reporter gene on the plasmid pUCD607 [15, 94], P. fluorescens 8866 and $P$. putida F1 with chromosomally integrated lux CDABE responding to soil pollution by different chlorobenzene derivatives [138]. However, the latter two strains also responded to heavy metals such as $\mathrm{Zn}$ and $\mathrm{Cu}$ [26]. Biosensors for the detection of polychlorinated biphenyls (PCBs) have been constructed by fusions of the luxCDBAE with genes of plasmidial promoter/regulator genes (bphA1/BphS) coding for degradative enzymes or the chromosomal $t f d \mathrm{R}-t f d \mathrm{DII}$ genes of Ralstonia eutropha ENV307 (pUTK60), regulated by the presence of mono- or polychlorinated biphenyls [49, 72 ], with detection limits in the order of $0.8-110 \mathrm{mM}$ and of 0.15 and $1.5 \mathrm{mg} \mathrm{L}^{-1}$ for chlorobiphenyls and Aroclor, respectively [72]. Two $g f p$-based biosensors sensitive to 2,4-dichlorophenoxyacetic acid have been constructed by inserting the $g f p$ with the $t f d C I$ gene in $R$. eutropha [36], and by the fusion of $g f p$ with the orf0bphA1 gene in P. fluorescens [13]. A luc-inserted Arthrobacter chlorophenolicus responding to 4-chlorophenol in soil has been successfully used by Elväng et al. [33] for monitoring the remediation of polluted soils. An assessment of phenanthrene bioavailability and degradation potential in soil has been obtained using the $g f p$-inserted phenanthrene-degrading Sphingomonas paucimobilis EPA505 strain, producing green fluorescence during the phenanthrene degradation [116]. Luminescent biosensors can also effectively detect explosive residues in soil [114], thus being very useful in assisting the remediation strategies of polluted soils (e.g. military proving grounds). 
A particularly relevant class of organic pollutants in agriculture is antibiotics, which can accumulate in significant amounts [124], with detrimental effects on soil microbial diversity and functionality. An E. coli strain carrying a gene fusion between the plasmidial Ptet conferring resistance to tetracycline and $g f p$ genes constructed by Hansen et al. [45], expressed the GFP when exposed to Streptomyces rimosus in soil microcosms. To our knowledge this was the only antibiotic biosensor used for detecting antibiotics in soil.

\section{Detection of emerging pollutants}

Soil is rich of natural nanomaterials but is also constantly subject to the accumulation of manufactured nanoparticles, increasingly used for commercial applications. Although there is a general consensus that beside their beneficial effects in crop protection, the manufactured nanoparticles may have also negative effects on soil microorganisms. Currently, there is no suitable protocol for the assessment of the bioavailability of the manufactured nanoparticles in soil, and specific whole-cell biosensors may be very useful for the related risk assessment. Bondarenko et al. [14] and Martineau et al. [81] used the lux -based metal-inducible $P$. putida KT2440 to assess the bioavailability of $\mathrm{CuO}$ and $\mathrm{ZnO}$ nanoparticles in the wheat rhizosphere, showing a dose-dependent inhibition of cell metabolism upon exposure to nanoparticles, caused by the quantitative release of $\mathrm{Cu}$ and $\mathrm{Zn}$ from the $\mathrm{CuO}$ and $\mathrm{ZnO}$ nanoparticles, which could be only partially quenched by the release of root exudates [81]. These results, though need further confirmation in next soil studies, well illustrate how the use of whole-cell biosensors can help in addressing the effects of emerging pollutants on soil microorganisms; in fact, relying on these early studies the negative impact of nanoparticles on microorganisms seem more related to the massive release of heavy metals nearby the cell wall rather than to nanoparticle size and surface properties (e.g. roughness, zeta potential).

The Bacillus subtilis 1S34 strain, carrying luciferase gene fusion with various five promoters responding to inhibitors of fatty acid, DNA, cell wall and protein synthesis have been successfully tested with several antibiotics [128], may be tested for assessing the bioavailability of antibiotic residues in soil. These reporter strains seem promising because $B$. subtilis is a soil-borne microorganism, which should therefore be insensitive to soil factors.

\section{Biosensors for detecting bioactive substances and cell stress}

A bioactive compound is any substance triggering a response in living organisms, and there is an ever increasing interest in use them as biostimulants in agriculture, as they can regulate and enhance physiological processes and growth efficiency at crop level. There is increasing evidences that trace amounts of several plant, animal and microbial secondary metabolites [63], soil-borne humic substances [127], and volatile organic compounds [79] are bioactive towards soil microorganisms and plant roots, and can enhance plant vigour, yields and quality. However, it should be born in mind that plant responses can be either positive or negative depending on the substance bioactivity and dose, but in the polyphasic soil environment it ultimately depends on its bioavailability, and nowadays the mode of action of biostimulants is still poorly understood. Biosensor holds the potentials to report the presence and bioavailability of natural or synthetic bioactive molecules eliciting responses of fundamental importance for the ecological interactions in agro-ecosystems, such as competition, defence, attraction, signalling, antibiosis. A classical and agriculturally relevant plant/microbe interaction is the legume-Rhizobium where plant flavonoid compounds control early stages of the symbiosis by activating the rhizobial nod genes. A Rhizobium reporter based on a nodC-lacZ fusion was constructed by Bolanos Vasquez and Warner [9] to study activation by six different flavonoids from host bean plants. Identification of more specific molecular signals regulating bacterial growth and activity in the rhizosphere have been discovered with the reporter gene technique $[2,80,105]$ and have allowed to identify specific rhizosphere-activated promoters in main rhizobacteria such as Rhizobium sp. and Pseudomonas sp. A $g f p$-inserted Rhizobium reporter strain was constructed by Allaway et al. [2] to identify the bacterial promoter genes activated in the rhizosphere, and several promoters controlling the syntheses of thiamine and cyclic glucan synthesis, controlling methionine synthesis or putrescine uptake were identified. An assessment of heavy metal impact on rhizobia as well as of the changes in the plant root exudation profile in metal-polluted soils were obtained using a Rhizobium leguminosarum luxtagged reporter strain [96, 100]. Whole-cell biosensors also gave an important contribution to the understanding of the cell-cell communication and to the cell densitydependent gene regulation in the rhizosphere. It is well established that a large fraction of rhizobacteria produces different $\mathrm{N}$-acyl-L-homoserine lactone (AHL) molecules, which mediate bacterial cell-cell communication [32], and Zhang and Pierson [144] demonstrated that AHLregulated gene is also a key factor for root colonization by rhizobacteria. The knowledge of the genes responding to AHL and structurally similar compounds has allowed the construction of whole-cell bacterial biosensors expressing the GFP ([5, 119]; Burmølle et al. 2003). Seen the current interests around biostimulants enhancing plant growth and health, development of biosensors capable of 
signalling the bioavailability plant stimulants are of sure interest in modern agriculture.

Biosensors indicating cell stress have been constructed by inserting the lux gene under control of promoters responding to general stress conditions such as heat shocks (e.g. dnaK), of protein-damage sensitive genes (e.g. grpE), oxidative stress (e.g. katG), or promoters sensitive to membrane damages (e.g. fabA) in enteric bacteria such as E. coli and S. typhimurium [132, 136]. Lux - and $g f p$-constructs of genes involved in the DNA repair (SOS response) have been transformed in soil bacteria to detect the presence of genotoxic substances [92, $95,102,110]$.

\section{Current limitations and prospects of whole-cell biosensors}

Whole-cell biosensors fulfil most of the technical requirements of analytical chemistry such as high specificity, sensitivity and reproducibility, also required by the official methods of environmental analysis (86/278/CEE). In addition, whole-cell biosensors provide rapid responses, require relatively simple preparation methodologies and cheap detection systems. However, biosensors still have some limitations in duration and stability of response, mainly due to biological factors. Main current limitations are the variable biosensor capacity during the monitoring tests and lack of specificity for particular classes of analyte. Studies on organic pollutant bioavailability in soil involve the use of organic solvents (e.g. ethanol), for example to extract BTEX [140] or surfactants to extract phenanthrene [40]. Interferences of organic solvents and surfactants on the reporter specificity is known since the early biosensor applications, when Heitzer et al. [51] reported that several strains (e.g. P. fluorescens HK44) responded to both organic contaminants and extraction solvents, because also the latter influence the microbial metabolic pathways leading to the reporter gene expression. The same occurred for constitutive reporter strains, even for commercial systems such as the MicroTox ${ }^{\circledR}$
[47]. This problem, which can also be caused by the different reconstitution media needed for the resuscitation of freeze-dried biosensors prior to the assay (Table 2), must be properly addressed for any biosensor test and can be effectively circumvented with proper parallel control experiments. Moreover, the simultaneous analysis of responses of a constitutive and inducible strain for the same analyte can much improve the interpretation of the signals [85]. New designs of specificity for the reporter bacteria, e.g. for broad- and narrow-range activation by organic pollutants must be developed further; one example is that of transcription activators such as $n a d R, x y l R$, $x y l \mathrm{~S}, d m p \mathrm{R}$ involved in the aromatic pollutant degradation (e.g. benzene derivatives), characterized by higher specificity than previously used promoters.

\section{Towards portable biosensors}

A great improvement of the applicability of biosensors to agricultural production and soil protection will come from the further advancements in miniaturization and portability of the signal detection systems for real-time detection and from the insertion of different reporter genes allowing the construction of microbial strains permitting simultaneous multi-analyte detection. The importance of onsite and online application of bioreporters was known since the early whole biosensor constructions. For example, Applegate et al. [6] used the P. fluorescens 5RL and P. putida TVA8 indicating naphthalene and toluene bioavailability, respectively, detecting the bioluminescence using a portable photomultiplier and compared the results with an off-site GC/MS analysis, showing consistent trends of environmental toxicity. A more recent example of portable biosensor is the ROTAS $^{\circledR}$ (Rapid Onsite Toxicity Audit System), allowing for the field assessment of toxicity by measuring the decrease of the $V$. fischeri bioluminescence. While such portable systems have been used worldwide with good reproducibility levels, portable detection systems can be considered still in their infancy. A reporter strain

Table 2 Reconstitution media needed for reporter bacteria used in cellular biosensor tests

\begin{tabular}{|c|c|}
\hline Whole-cell biosensor & Reconstitution medium \\
\hline P. putida KT2440 (pLYS24-davT-lux) & $\mathrm{M} 9+$ benzoate + glucose with no $\mathrm{NH}_{4} \mathrm{Cl}$ \\
\hline P. fluorescens DF5740E7, DF57-N3, DF57-11D1 & Liquid Luria-Bertani medium $+0.9 \% \mathrm{NaCl}$ \\
\hline P. fluorescens HK44 (pUTK21) & Yeast-peptone-glucose extract $+1 \mathrm{M} \mathrm{KCl}$ \\
\hline V. fischeri (BioTox ${ }^{\circledR}$ test) & $2.0 \% \mathrm{NaCl}$ \\
\hline C. metallidurans (BIOMET $\left.{ }^{\circledR}\right)$ & Tris salt medium $(\mathrm{TSM})+\mathrm{Fe}\left(\mathrm{NH}_{4}\right)_{3}$-citrate + gluconate \\
\hline P. aureofaciens PGS12 & Minimal Ayer culture medium + 25 mM HEPES \\
\hline R. leguminosarum 3841 (pOT1) & Acid minimal salt (AMS) + thiamine \\
\hline P. fluorescens A506 (pTS) & M9 medium + thiamine + Casaminoacids + Noble agar \\
\hline
\end{tabular}

a HEPES is the 4-(2-hydroxyethyl)-1-piperazineethanesulfonic acid 
expressing GFP and yellow and red fluorescent protein variants (YFP, RFP) has been constructed but the interpretation of multiple responses will also require sophisticate detection systems. A promising application of embedded $V$. fischeri for the in situ assay of naphthalene toxicity was presented by Jouanneau et al. [62], which may also be applied to the study of contaminated sites.

\section{Biosensors assisting future agriculture}

Biosensors are in perspective the best analytical tools for reporting the occurrence of chemical signals in the plant-microbe interactions because generally, the effector molecules are released in trace amounts and localized in hot spots, and this makes problematic their detection with chemical methods. In the future, more studies should be made to compare results using different scales of investigation; there are unique opportunities in comparing single-cell studies based on sensitive, fluorescent biosensors in combination with advanced confocal laser scanning microscopy with larger samples such as soil extracts or slurries, and with whole plant-soil detection studies based on direct bioluminescence recorded under a sensitive camera. Online monitoring using immobilized reporter cells on optic fibres [50] should be tested further; a recent application of optic fibres to monitor reporter bacteria in porous media was reported by Yolcubal et al. [142].

Biosensors can also lead to great improvement in crop nutrient use efficiency. What is the theoretical relationship between plant and rhizosphere microorganisms in relation to nutrient availability? If the theoretical assumption that 'the winner takes it all', except for the nutrient losses, then the plant and microbial genetic activity in the presence of available nutrients should be a mirror image of each other (Fig. 2). Although the nutrient use efficiency (NUE) is an inherent plant trait [143], in agricultural soils the competition between plants and rhizosphere microorganisms can decrease the crop NUE due to microbial immobilization. We believe that biosensors are the only currently available tools to monitor the real-time nutrient uptake by rhizosphere microorganisms.

Application of biosensors to the soil-plant microbe interactions in the rhizosphere of agricultural soils may unlock the not fully unexploited soil biological potential in terms of plant growth and protection. For example, using the P. fluorescens F113 biosensor Smith et al. [117] reported that Pythium ultimum molecules which downregulated the rrn promoters controlled the ribosomal RNA synthesis, in the reporter strain and thus controlled the cellular growth rate. In another study, Lee and Cooksey [74] found that colonization of the root rotting Phytophthora parasitica by the fungal suppressive rhizobacteria Pseudomonas putida 06909 strain activated the bacterial promoters controlling ATP-binding cassettes (ABC transporters), which are transmembrane transporters translocating various substrates across cell membranes. These studies demonstrated that biosensors allow to study the gene-regulating signals in the rhizosphere and this information may be of interest for developing new biological plant-protecting strategies.

Biosensors may be used to assess the effects of genetically modified (GM) crops on soil properties, particularly their potential impact on nutrient cycling and plant/ microbe interactions. Biosensors can be used to investigate the soil modification induced by GM plant roots in soil and gain an early understanding on soil functions, particularly in the rhizosphere. However, the main concern about GM crops is the release and persistence of transgenic DNA into soil, and to our knowledge there is still no whole-cell biosensors capable of signalling the presence of specific DNA sequences. In this field, chemical biosensors are much more developed than wholecell biosensors. Also the detection of volatile organic compounds (VOCs) by whole-cell biosensors may be a valuable tool for a better understanding of the ecological implications and impact of the soil VOCs emissions, and on the transfer of pollutant VOCs to the atmosphere. Gil et al. [38] constructed a lux-inserted E. coli biosensor for VOCs detection, which was calibrated and tested with benzene. However, to our knowledge no applications to soil studies have been reported. In this sense, whole-cell biosensors may contribute to the frame of an ecological theory of soil microbial communities relying on the indication of plant/microbe and microbe/microbe interactions. An interesting microarrays for multiple bioreporter detection based on E. coli lux-based bioreporter array capable of detecting up to 689 transcriptional events presented by van Dyk et al. [133] also holds potential for soil applications.

To our knowledge there is currently no biosensors for reporting sulphur (S) bioavailability, mainly because the $\mathrm{S}$ bacterial metabolism is less known as compared to that of $\mathrm{C}, \mathrm{N}$ and $\mathrm{P}$, and also because $\mathrm{S}$ concentration in the environment has not been a limiting factor due to the large past emissions. However, S deficiency in agricultural soils is now emerging mainly due to the low use of fertilizer $\mathrm{S}$, high $\mathrm{S}$ absorption by the crop genotypes and the constantly decreasing trend of $\mathrm{S}$ emissions, and actual sensing of $\mathrm{S}$ reporting bioavailability may contribute to improve the crop production, as S deficiency symptoms in crops are often confused with those of $\mathrm{N}, \mathrm{Mg}, \mathrm{Mn}$ or $\mathrm{Zn}$ deficiency. The main form of bioavailable $\mathrm{S}$ in soil is organic $\mathrm{S}$, mineralized to $\mathrm{SO}_{4}{ }^{2-}-\mathrm{S}$ which is taken up by plants, and the chemical methods of soil analysis poorly define the bioavailable $\mathrm{S}$ pool in soil. Inserting of bacterial promoters such as atsA, tau, ytm would be suitable 


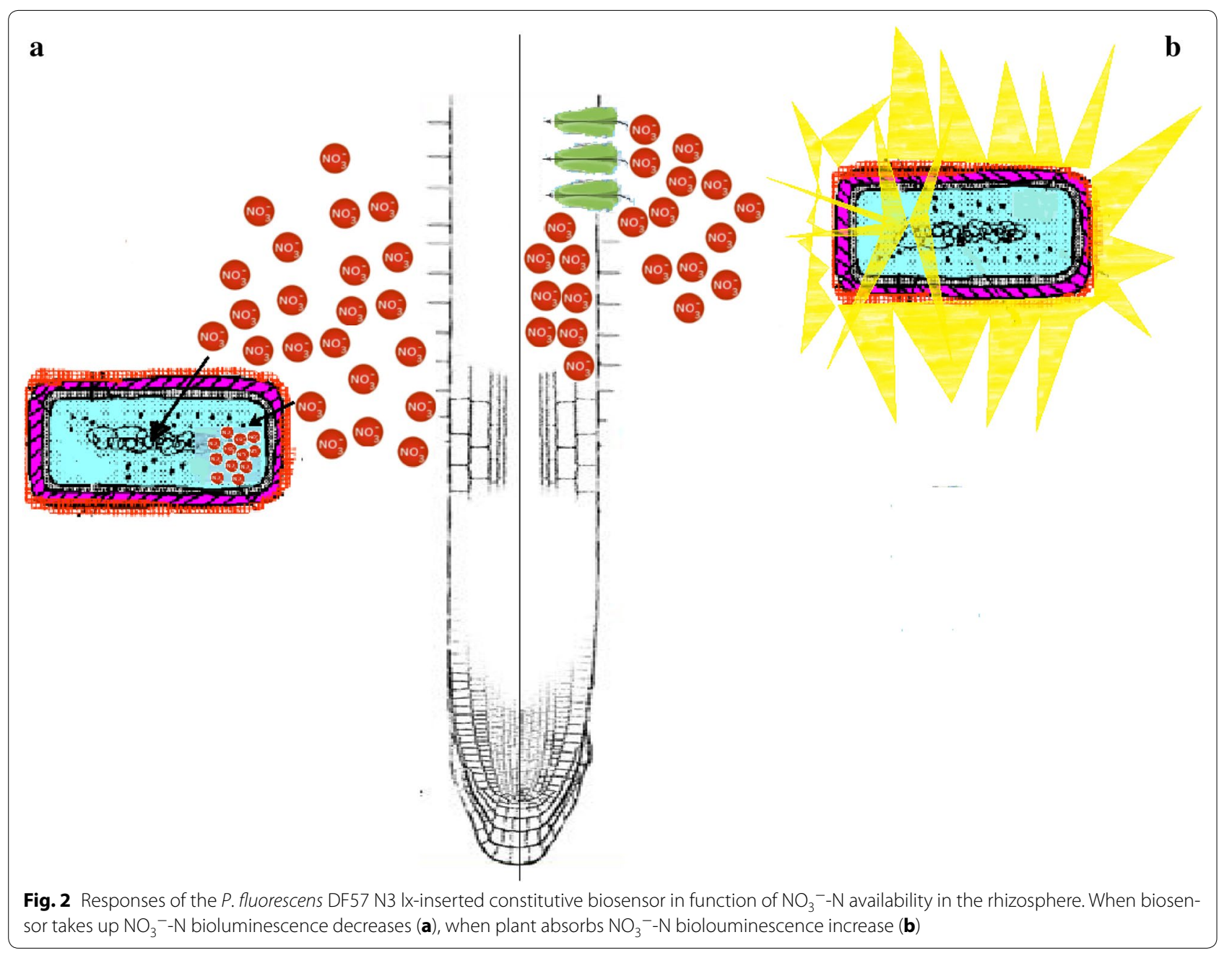

for constructing biosensors responding to bioavailability of inorganic, organic and volatile $\mathrm{S}$ have been identified, as demonstrated by fusion of the $\mathrm{S}$ responding promoters with the lacZ. Pioneer applications of whole-cell biosensors for the study of S bioavailability in the rhizosphere have been reviewed by Goron and Raizada [39].

\section{Integrative sensing the agro-environment}

Problems of future agriculture can be effectively addressed using biosensors to reduce risks, optimize the efficiency of plant mineral nutrition and control plant-microbe interactions. These main agricultural aspects can be monitored from future field trials specifically designed to collect, collate and analyse biosensor responses with formalized systems that make such responses easy-to-understand by farmers and advisors. New types of biosensors will be also needed to increase their sensitivity to environmental change. An improvement of the mechanisms of molecular recognition which will likely allow the construction of new and more stable and selective biosensors by means of the use of receptor proteins [75], also including the periplasmic proteins, which may also produce signals by the protein fusion with fluorophores [29]. These 'protein' based biosensors may provide complementary information on to those of the 'genetic' biosensors and may also provide new information on the ability of microorganisms to act as ligands for elements, molecules and substances (e.g. humic substances) in soil, and therefore to not necessarily signal the absorption of analytes as a result of their assimilation. A technological development in this sense may follow that of Okumoto et al. [93] who studied the responsible excitation mechanisms during the neuronal transmission, where how the concentration of glutamic acid inside and to the surface of the cells was indicated by the fluorescent GLU/ASP binding protein ybeJ of $E$. coli fused with two variants of the GFP. These biosensors respond to the extracellular concentrations of glutamic 
acid and may be used in future for the in vivo monitoring of the $\mathrm{N}$ forms assimilated by soil microorganisms. A great advancement in our understanding of soil functioning may also come from more whole-cell biosensors with engineered promoters coding for the synthesis of periplasmic $A B C$ proteins involved in the assimilation of large organic molecules from the external membrane towards the cytoplasm in soil microorganisms [89]. More observations on the functioning of these mechanisms may revolutionize our knowledge on the dynamics of polysaccharides, peptides, of siderophores and other organic molecules such as those present in the humic substances [99] or those regulating the microbial activity in the rhizosphere.

Another unanswered question in soil biochemistry is the origin and location of enzyme activity in soil. It is generally accepted that the soil enzyme activity is predominantly extracellular, and therefore not directly related to the microbial metabolic activity; however, the induction and repression of the soil enzymatic activity upon the availability of organic substrates and end products, respectively has been often reported in the rhizosphere and bulk soil (e.g. [106, 107]). The increasing knowledge on the regulation of functional genes of soil-borne microorganisms may lead to construct whole-cell biosensors indicating the expression of gene coding for enzyme activities. For example, Schreiter et al. [111] inserted the lux gene under the control of promoter sequences of gene coding for the alkaline phosphatase into the two strains of the blue-green algae Synechococcus PCC 7942, expressing the enzyme under P-deficiency (M 1415) and under N-deficiency conditions (NblA-2000). Whole-cell biosensors may also provide new evidences on the topological localization of microorganisms in the soil habitat, in relation to the availability of specific compounds. This may be achieved following the approaches of Møller et al. [88] and Leveau and Lindow [70] for the study of bacterial biofilms and epiphytic bacteria, respectively, coupled with micropedology based on the use of soil thin sections coupled with the use of biosensors expressing fluorescent proteins.

\section{Concluding remarks}

Biosensor technology is constantly developing thanks to the increasing knowledge on the regulation of key functional genes in soil-borne microorganisms and precision of gene fusion technologies, and it is anticipated that next biosensors will be capable of signalling the bioavailability of specific analyte and the occurrence of ecological interactions with higher sensitivity and lower interference also in the soil environment. The broader use of biosensors may lead to a faster answering to basic and long-standing ecological questions in soil and environmental sciences.
Because biosensors indicate analyte bioavailability and key biological interactions at sub-optimal and sub-toxic concentrations with far superior sensitivity than chemical methods, their responses should be included in both development of precision agriculture and in risk assessment for contaminated/remediated soils. However, the ever increasing construction of whole-cell biosensors is still not reflected in the real world where these tools are currently not routinely used when evaluating, for example, the crop nutrient efficiency or the environmental risk assessment, and most of the constructed biosensors are used for scientific research only and do not find practical application by both advisors and environmental agencies. Lack of knowledge and expertise with biosensors is also a main hindrance for including the whole-cell biosensors in the official methods for soil and environmental analysis. We are fully confident that existing and next generation of biosensors can be considered as tools for new paradigmatic strategies that improve agronomical practice and soil management and remediation, and should already integrate the soil chemical analysis of nutrient availability currently used by agricultural and environmental advisors.

\section{Authors' contributions}

The two authors equally contributed to the preparation of the present review article. Both authors read and approved the final manuscript.

\section{Competing interests}

The authors declare that they have no competing interests.

Received: 13 October 2015 Accepted: 14 March 2016

Published online: 31 March 2016

\section{References}

1. Alexander M. Biochemical ecology of soil microorganisms. Ann Rev Microbiol. 1964;18:217-50

2. Allaway D, Schofield NA, Leonard ME, Gilardoni L, Finan TM, Poole PS Use of diffrential fluorescence induction and optical trapping to isolate environmentally induced genes. Environ Microbiol. 2001;3:397-406.

3. Amaro F, Turkewitz AP, Martin-Gonzalez A, Gutiérrez JC. Whole-cell biosensors for detection of heavy metal ions in environmental samples based on metallo thionein promoters from Tetrahymena thermophila. Microb Biotech. 2011:4:513-22.

4. Amaro F, Turkewitz AP, Martin-Gonzalez A, Gutiérrez JC. Functional GFP-metallo thionein fusion protein from Tetrahymena thermophila: a potentialwhole-cell biosensor for monitoring heavy metal pollution and a cell model to study metallothionein over production effects. Biometals. 2014;27:195-205.

5. Andersen JB, Sternberg C, Poulsen JK, Bjørn SP, Givskov M, Molin S. New unstable variants of green flourescent protein for studies of transient gene expression in bacteria. Appl Environ Microb. 1998;64:2240-6.

6. Applegate BM, Kehrmeyer SR, Sayler GS. A chromosoally based todluxCDABE whole-cell reporter for benzene, toluene, ethylbenzene, and xylene (BTEX) sensing. Appl Environ Microb. 1998;64:2730-5.

7. Ascher J, Ceccherini MT, Landi L, Mench M, Pietramellara G, Nannipieri P, Renella G. Composition, biomass and activity of microflora, and leaf yields and foliar elemental concentrations of lettuce, after 
in situ stabilization of an arsenic-contaminated soil. Appl Soil Ecol. 2009;41:351-9.

8. Belkin S. Microbial whole-cell sensing systems of environmental pollutants. Curr Opin Microbiol. 2003;6:206-12.

9. Bolanos-Vasquez MC, Werner D. Effects of Rhizobium tropici, R. etli, and $R$. leguminosarum bv. phaseoli on nod gene-inducing flavonoids in root exudates of Phaseolus vulgaris. Mol Plant Microbe Interact. 1997; 10:339-46.

10. Branco R, Cristóvão A, Morais PV. Highly sensitive, highly specific whole-cell bioreporters for the detection of chromate in environmental samples. PLoS One. 2013;8:e54005.

11. Brandt KK, Pedersen A, Sørensen J. Solid-phase contact assay that uses a lux-marked Nitrosomonas europaea reporter strain to estimate toxicity of bioavailable linear alkylbenzene sulfonate in soil. Appl Environ Microb. 2002;68:3502-8.

12. Brandt KK, Holm PE, Nybroe O. Evidence for bioavailable copperdissolved organic matter complexes and transiently increased copper bioavailability in manure-amended soils as determined by bioluminescent bacterial biosensors. Environ Sci Technol. 2008;42:3102-8.

13. Boldt T, Sørensen J, Karlson U, Molin S, Ramos C. Combined use of different Gfp reporters for monitoring single cell activities of a genetically modified PCB degrader in the rhizosphere of alfalfa. FEMS Microbiol Ecol. 2004;48:139-48.

14. Bondarenko O, Ivask A, Käkinena A, Kahru A. Sub-toxic effects of CuO nanoparticles on bacteria: kinetics, role of $\mathrm{Cu}$ ions and possible mechanisms of action. Environ Pollut. 2012;169:81-9.

15. Boyd EM, Killham K, Meharg AA. Toxicity of mono-, di- and tri-chlrophenols to lux marked terrestrial bacteria, Burkholderia species Rasc c2 and Pseudomonas fluorescens. Chemosphere. 2001;43:157-66.

16. Brookes PC, Powlson DS, Jenkinson DS. Measurement of microbial biomass phosphorus in soil. Soil Biol Biochem. 1982;14:319-29.

17. Brouwer H, Murphy T, McArdle L. A sediment-contact bioassay with Photobacterium phosphoreum. Environ Tox Chem. 1990;9:1353-8.

18. Bulich AA, Isenberg DL. Use of the luminescent bacterial system for the rapid assessment of aquatic toxicity. ISA T. 1981;20:29-33.

19. Burlage RS, Sayler GS, Larimer F. Monitoring of naphthalene catabolism by bioluminescence with nah-lux transcriptional fusions. J Bacteriol. 1990;172:4749-57.

20. Burlage RS, Palumbo AV, Heitzer A, Sayler G. Bioluminescent reporter bacteria detect contaminants in soil samples. Appl Biochem Biotech. 1994:45:731-40.

21. Buyer JS, Sasser M. High throughput phospholipid fatty acid analysis of soils. Appl Soil Ecol. 2012;61:127-30.

22. Casavant NC, Thompson D, Beattie GA, Phillips GJ, Halverson LJ. Use of a site-specific recombination-based biosensor for detecting bioavailable toluene and related compounds on roots. Environ Microbiol. 2003;5:238-49.

23. Collard JM, Provoost A, Taghavi S, Mergeay M. A new type of Alcaligenes eutrophus $\mathrm{CH} 34$ zinc resistance generated by mutations affecting regulation of the $\mathrm{cnr}$ cobalt-nickel resistance system. J Bacteriol. 1993;175:779-784.

24. Corbisier PH, Ji G, Nuyts G, Mergeay M, Silver S. I UxAB gene fusions with the arsenic and cadmium resistance operons of Staphylococcus aureus plasmid pl258. FEMS Microbiol Lett. 1993;110:231-8.

25. Corbisier PH, van der Lelie D, Borremans B, Provoost A, de Lorenzo V, Brown NL, Lloyd JR, Hobman JL, Csöregi E, Johansson G, Mattiasson B. Whole cell-and protein-based biosensors for the detection of bioavailable heavy metals in environmental samples. Anal Chim Acta. 1999;387:235-44.

26. Daunert S, Barett G, Feliciano JS, Shetty RJ, Shrestha S, Smith-Spencer W. Genetically engineered whole-cell sensing systems: coupling biological recognition with reporter genes. Chem Rev. 2000;100:2705-38.

27. Darwent MJ, Paterson E, McDonald AJS, Tomos AD. Biosensor reporting of root exudation from Hordeum vulgare in relation to shoot nitrate concentration. J Ex Bot. 2003;54:325-334

28. De Angelis KM, Ji P, Firestone MK, Lindow SE. Two novel bacterial biosensors for detection of nitrate availability in the rhizosphere. Appl Environ Microb. 2005;71:8537-47.

29. Deuschle K, Okumoto S, Fehr M, Looger LL, Kozhkh L, Frommer WB. Construction and optimization of a family of genetically encoded metabolite sensors by semirational protein engineering. Protein Sci. 2005;14:2304-14.

30. Di Gennaro P, Bruzzese N, Anderlini D, Aiossa M, Papacchini M, Campanella $L$, Bestetti $G$. Development of microbial engineered whole-cell systems for environmental benzene determination. Ecotox Environ Safe. 2011:74:542-9.

31. Dutka BJ, Kwan KK, Rao SS, Jurkovic A, Mcinnis R, Palmateer GA, Hawkins B. Use of bioassays to evaluate river water and sediment quality. Environ Tox Water. 1991;6:309-27.

32. Elasri M, Delorme S, Lemanceau P, Stewart G, Laue B, Glickmann E, Oger PM, Dessaux Y. Acyl-homoserine lactone production is more common among plant-associated Pseudomonas spp. than among soil-borne Pseudomonas spp. Appl Environ Microb. 2001;67:1198-209.

33. Elväng AM, Westerberg K, Jernberg C, Jansson JK: Use of green fluorescent protein and luciferase biomarkers to monitor survival and activity of Arthrobacter chlorophenolicus A6 cells during degradation of 4-chlorophenol in soil. Env Microbiol. 2001;3:32-42

34. Espinosa-Urgel M, Ramos JL. Expression of a Pseudomonas putida involved in lysine metabolism is induced in the rhizosphere. Appl Environ Microb. 2001;67:5219-24.

35. Fernandez S, Shingler V, de Lorenzo V. Cross-regulation by XyIR and DmpR activators of Pseudomonas putida suggests that transcriptional control of biodegradative operons evolves independently of catabolic genes. J Bacteriol. 1994;176:5052-8.

36. Füchslin HP, Rüegg I, van der Meer JR, Egli T. Effect of integration of a GFP reporter gene on fitness of Ralstonia eutropha during growth with 2,4-dichlorophenoxyacetic acid. Environ Microbiol. 2003;5:878-87.

37. Giagnoni L, Magherini F, Landi L, Taghavi S, Modesti A, Bini L, Nannipieri P, van der Lelie D, Renella G. Extraction of microbial proteome from soil: potential and limitations assessed through a model study. Eur J Soil Sci. 2011;62:74-81.

38. Gil GC, Mitchell RJ, Chang ST, Gu MB. A biosensor for the detection of gas toxicity using a recombinant bioluminescent bacterium. Biosens Bioelectron. 2000;15:23-30.

39. Goron TL, Raizada MN. Current and future transgenic whole-cell biosensors for plant macro- and micronutrients. Crit Rev Plant Sci. 2014;33:392-413.

40. Gu MB, Chang ST. Soil biosensor for the detection of PAH toxicity using an immobilized recombinant bacterium and a biosurfactant. Biosens Bioelectron. 2001;16:667-74

41. Gu H, Lalonde S, Okumoto S, Looger LL, Scharff-Poulsen AM, Grossman AR, Kossmann J, Jakobsen I, Frommer WB. A novel analytical method for in vivo phosphate tracking. FEBS Lett. 2006;580:5885-93.

42. Gutiérrez JC, Amaro F, Martín-González A. Heavy metal whole-cell biosensors using eukaryotic microorganisms: an updated critical review. Front Microbiol. 2015;6:48.

43. Hansen LH, Sørensen SJ. Versatile biosensor vectors for detection and quantification of mercury. FEMS Microbiol Lett. 2000;193:123-7.

44. Hansen LH, Sørensen SJ. The use of whole-cell biosensors to detect and quantify compounds or conditions affecting biological systems. Microb Ecol. 2001;42:483-94.

45. Hansen LH, Ferrari B, Sørensen AH, Veal D, Sørensen SJ. Detection of oxytetracycline production by Streptomyces rimosus in soil microcosms by combining whole-cell biosensors and flow cytometry. Appl Environ Microb. 2001;67:239-44

46. Hao OJ, Shin CJ, Lin CF, Jeng FT, Chen ZC. Use of microtox tests for screening industrial wastewater toxicity. Water Sci Technol. 1996;34:43-50.

47. Harkey GA, Young TM. Effect of soil contaminant extraction method in determining toxicity using the Microtox ${ }^{\circledR}$ assay. Environ Tox Chem. 2000;19:276-82.

48. Harmsen J. Measuring bioavailability: from a scientific approach to standard methods. J Environ Qual. 2007;36:1420-8.

49. Hay AG, Rice JF, Applegate BM, Bright NG, Sayler GS. A bioluminescent whole-cell reporter for detection of 2,4-dichloroophenoxyacetic acid and 2,4-dichlorophenol in soil. Appl Environ Microb. 2000;66:4589-94.

50. Heitzer A, Malachowsky K, Thonnard J, Bienkowski P, White D, Sayler G. Optical biosensor for the environmental on-line monitoring of naphthalene and salicylate bioavailability with an immobilised bioluminescent catabolic reporter bacterium. Appl Environ Microb. 1994:60:1487-94. 
51. Heitzer A, Applegate B, Kehrmayer S, Pinkart H, Webb OF, Phelps TJ, White DC, Sayler GS. Physiological considerations of lux reporter fusions. J Microbiol Meth. 1998;33:45-57.

52. Hermens J, Busser F, Leeuwanger P, Musch A. Quantitative structureactivity relationships and mixture toxicity or organic chemicals in Photobacterium phosphoreum: the Microtox Test. Exotox Environ Safe. 1985;9:17-25.

53. Huang PM, Germida JJ. Chemical and biological processes in the rhizosphere: metal pollutants. In: Huang PM, Bollag JM, Senesi N, editors. Interacions between soil particles and microorganisms. Impact in terrestrial ecosystems. IUPAC sereis on analytical and physical chemistry of environmental systems, vol. 8. Chichester: Wiley; 2002. p. 381-438

54. Kelsey JW, Kottler BD, Alexander M. Selective chemical extractants to predict bioavailability of soil-aged organic chemicals. Environ Sci Technol. 1996;31:214-7.

55. King JMH, Digrazia PM, Applegate B, Burlage R, Sanseverino J, Dunbar $P$, Larimer F, Sayler GS. Rapid, sensitive bioluminescent reporter technology for naphthalene exposure and biodegradation. Science. 1990;249:778-81.

56. Koch B, Worm J, Jensen LE, Højberg O, Nybroe $\varnothing$. Carbon limitation induces sS-dependent gene expression in Pseudomonas fluorescens in soil. Appl Environ Microb. 2001;67:3363-70.

57. IUPAC. Compendium of chemical terminology. In: McNaught AD, Wilkinson A editors. Volume 2. Oxford: Blackwell Scientific Publications; 1997. ISBN 0-9678550-9-8. doi:10.1351/goldbook.

58. Jaeger CH, Lindow SE, Miller W, Clark W, Firestone MK. Mapping of sugar and amino acid availability in soil around roots with bacterial sensors of sucrose and tryptophan. Appl Environ Microb. 1999;65:2685-90.

59. Jenkinson DS, Ladd JN. Microbial biomass in soil: measurement and turnover. In: Paul EA, Ladd JN, editors. Soil biochemistry, vol. 5. Basel: Marcel Dekker; 1981. p. 415-71.

60. Jennings VLK, Rayner-Brandes MH, Bird DJ. Assessing chemical toxicity with the bioluminescent photobacterium (Vibrio fischeri): a comparison of three commercial systems. Water Res. 2001;35:3448-56.

61. Jensen LE, Nybroe $\varnothing$. Nitrogen availability to Pseudomonas fluorescens DF57 is limited during decomposition of barley straw in bulk soil and in the barley rhizosphere. Appl Environ Microb. 1999;65:4320-8.

62. Jouanneau S, Durand-Thouand MJ, Thouand G. Design of a toxicity biosensor based on Aliivibrio fischeri entrapped in a disposable card. Environ Sci Pollut Res. 2015. doi:10.1007/s11356-015-4942-4

63. Karlovsky P. Secondary metabolites in soil ecology. Berlin, Heidelberg: Springer-Verlag; 2008.

64. Kim Y, Wegner $C E$, Liesack W. Soil metatranscriptomics. In: Nannipieri P, Pietramellara G, Renella G, editors. Omics in soil science. Norfolk: Caster Academic Press; 2014. p. 63-93.

65. Li YF, Li FY, Ho CL, Liao VHC. Construction and comparison of fluorescence and bioluminescence bacterial biosensors for the detection of bioavailable toluene and related compounds. Environ Pollut. 2008;152:123-9.

66. Köhler S, Belkin S, Schmid RD. Reporter gene bioassays in environmental analysis. Fresen J Anal Chem. 2000;366:769-79.

67. Kragelund L, Hosbond C, Nybroe $\varnothing$. Distribution of metabolic activity and phosphate starvation response of lux-tagged Pseudomonas fluorescens reporter bacteria in the barley rhizosphere. Appl Environ Microb. 1997;63:4920-8.

68. Kuiper I, Bloemberg GV, Noreen S, Thomas-Oates JE, Lugtenberg BJJ. Increased uptake of putrescine in the rhizosphere inhibits competitive root colonization by Pseudomonas fluorescens strain WCS365. Mol Plant Microbe Interact. 2001;14:1096-104.

69. Lappalainen J, Juvonen R, Vaajasaari K, Karp M. A new flash method for measuring the toxicity of solid and colored samples. Chemosphere. 1999;38:1069-83.

70. Leveau JHJ, Lindow SE. Appetite of an epiphyte: quantitative monitoring of bacterial sugar consumption in the phyllosphere. P Natl Acad Sci USA. 2001;98:3446-53.

71. Leveau JHJ, Lindow SE. Bioreporters in microbial ecology. Curr Opin Microbiol. 2002;5:259-65.

72. Layton AC, Muccini M, Ghosh MM, Sayler GS. Construction of a bioluminescent reporter strain to detect polychlorinated biphenyls. Appl Environ Microb. 1998:64:5023-6.
73. Layton AC, Gregory B, Schultz TW, Sayler GS. Validation of genetically engineered surfactant resistant bacteria as toxicity assessment tools. Ecotox Environ Safe. 1999;43:222-8.

74. Lee SW, Cooksey DA. Genes expressed in Pseudomonas putida during colonization of a plant-pathogenic fungus. Appl Environ Microb. 2000;66:2764-72.

75. Looger LL, Dwyer MA, Smith JJ, Helling HW. Computational design of receptor and sensor proteins with novel functions. Nature. 2003:423:185-9.

76. Maderova L, Paton Gl. Deployment of microbial sensors to assess zinc bioavailability and toxicity in soils. Soil Biol Biochem. 2013;66:222-8.

77. Maderova L, Watson M, Paton GI. Bioavailability and toxicity of copper in soils: integrating chemical approaches with responses of microbial biosensors. Soil Biol Biochem. 2011;43:1162-8.

78. Magrisso S, Erel Y, Belkin S. Microbial reporters of metal bioavailability. Microb Biotechnol. 2008;1:320-30.

79. Mancuso S, Taiti C, Bazihizina N, Costa C, Menesatti P, Giagnoni L, Arenella M, Nannipieri P, Renella G. Soil volatile analysis by proton transfer reaction-time of flight mass spectrometry (PTR-TOF-MS). Appl Soil Ecol. 2015;86:182-91.

80. Marco ML, Legac J, Lindow SE. Conditional survival as a selection strat egy to identify plant-inducible genes of Pseudomonas syringae. App Environ Microb. 2003;69:5793-801.

81. Martineau N, McLean JE, Dimkpaa CO, Britt DW, Anderson AJ. Components from wheat roots modify the bioactivity of $\mathrm{ZnO}$ and $\mathrm{CuO}$ nanoparticles in a soil bacterium. Environ Pollut. 2014;187:65-72.

82. Marschner P, Crowley DE. Physiological activity of a bioluminescent Pseudomonas fluorescens (strain 2-79) in the rhizosphere of mycorrhiza and non-mycorrhizal pepper (Capsicum annuum L.). Soil Biol Biochem. 1996;28:869-76.

83. Merulla D, Buffi N, Beggah S, Truffer F, Geiser M, Renaud PH, van der Meer JR. Bioreporters and biosensors for arsenic detection. Biotechnological solutions for a world-wide pollution problem. Curr Opin Biotech. 2013;24:534-41.

84. Michelini E, Cevenini L, Calabretta MM, Spinozzi S, Camborata C, Roda A. Field-deployable whole-cell bioluminescent biosensors: so near and yet so far. Anal Bioanal Chem. 2013;405:6155-63.

85. Mirasoli M, Feliciano J, Michelini E, Daunert S, Roda A. Internal response correction for fluorescent whole-cell biosensors. Anal Chem. 2002;74:5948-53.

86. Misra TK. Bacterial resistances to inorganic mercury salts and organomercurials. Plasmid. 1992:27:4-16.

87. Monod J. Recherche sur la croissance des cultures bacteriennes. PhD thesis. Hermann Ed., Paris: 1942.

88. Møller S, Sternberg C, Andersen JB, Christensen BB, Ramos JL, Givskov M, Molin S. In situ gene expression in mixed culture biofilms: evidence of metabolic interactions between community members. Appl Environ Microb. 1998;64:721-32

89. Momma K, Mishima Y, Hashimoto W, Mikami B, Murata K. Direct evidence for Sphingomonas sp. A1 periplasmic proteins as macromolecule-binding proteins associated with the $A B C$ transporter: molecular insights into alginate transport in the periplasm. Biochemistry. 2005:44:5053-64

90. Nies DH. Microbial heavy-metal resistance. Appl Microbiol Biot. 1999;51:730-50

91. Novick A, Weiner M. Enzyme induction as an all-or-none phenomenon. Proc Nat Acad Sci USA. 1957:43:553-66.

92. Norman A, Hansen LH, Sørensen SJ. Construction of a ColD cda promoter-based SOS-green fluorescent protein whole-cell biosensor with higher sensitivity toward genotoxic compounds than constructs based on recA, umuDC, or sul4 promoters. Appl Environ Microb. 2005;71:2338-46.

93. Okumoto S, Looger LL, Micheva KD, Reimer RJ, Smith SJ, FrommerWB. Detection of glutamate release from neurons by genetically encoded surfacedisplayed FRET nanosensors. P Natl Acad Sci USA. 2005;102:8740-5.

94. Palmer G, McFadzean R, Killham K, Sinclair A, Paton Gl. Use of lux-based biosensors for rapid diagnosis of pollutants in arable soils. Chemosphere. 1998:36:2683-97.

95. Park SH, Lee DH, Oh KH, Lee K, Kim CK. Detection of aromatic pollutants by bacterial biosensors bearing gene fusions constructed with 
the dnaK promoter of Pseudomonas sp DJ-12. J Microbiol Biotechn. 2002;12:417-22

96. Paton Gl, Palmer G, Burton M, Rattray EAS, McGrath SP, Glover LA, Killham K. Development of an acute and chronic ecotoxicity assay using lux-marked Rhizobium leguminosarum Biovar trifolii. Lett Appl Microbiol. 1997;24:296-300.

97. Pedersen LL, Smets BF, Dechesne A. Measuring biogeochemical heterogeneity at the microscale in soils and sediments. Soil Biol Biochem. 2015;90:122-38.

98. Peijnenburg WJGM, Zablotskaja M, Vijver MG. Monitoring metals in terrestrial environments within a bioavailability framework and a focus on soil extraction. Ecotox Environ Safe. 2007;67:163-79.

99. Piccolo A. The supramolecular structure of humic substances. Soil Sci. 2001;166:810-32.

100. Porteous F, Killham K, Meharg A. Use of a lux-marked rhizobacterium as a biosensor to assess changes in rhizosphere $C$ flow due to pollutant stress. Chemosphere. 2000;41:1549-54.

101. Quershi AA, Bulich AA, Isenberg DL. Microtox toxicity test systemswhere they stand today. In: Wells PG, Lee K, Blaise C, editors. Microscale testing in aquatic toxicology advances, techniques, and practice. Boca Raton: CRC Press; 1998. p. 185-99.

102. Rabbow E, Rettberg P, Baumstark C, Horneck G. SOS-LUX and LACFLUORO-TEST for the quantification of genotoxic and/or cytotoxic effects of heavy metal salts. Anal Chim Acta. 2002;456:31-9.

103. Ramanathan S, Ensor M, Daunert S. Bacterial biosensors for monitoring toxic metals. Trends Biotechnol. 1997;15:500-6.

104. Ramos C, Mølbak L, Molin S. Bacterial activity in the rhizosphere analysed at the single-cell level by monitoring ribosome contents and synthesis rates. Appl Environ Microb. 2000;66:801-9.

105. Rainey PB. Adaptation of Pseudomonas fluorescens to the plant rhizosphere. Environ Microbiol. 1999;1:243-57.

106. Renella G, Landi L, Ascher J, Ceccherini MT, Pietramellara G, Nannipieri P. Phosphomonoesterase production and persistence and composition of bacterial communities during plant material decomposition in soils with different $\mathrm{pH}$ values. Soil Biol Biochem. 2006;38:795-802

107. Renella G, Szukics U, Landi L, Nannipieri P. Quantitative assessment of hydrolase production and persistence in soil. Biol Fertil Soils. 2007:44:321-9.

108. Renella G, Ogunseitan O, Giagnoni L, Arenella M. Environmental proteomics: a long March in the pedosphere. Soil Biol Biochem. 2014;69:34-7.

109. Roca C, Olsson L. Dynamic responses of Pseudomonas fluorescens DF57 to nitrogen or carbon source addition. J Biotech. 2001;86:39-50.

110. Rosen R, Davidov Y, LaRossa RA, Belkin S. Microbial sensors of ultraviolet radiation based on recA': lux fusions. Appl Biochem Biotech. 2000;89:151-60.

111. Schreiter PPY, Gillor O, Post A, Belkin S, Schmidt RD, Bachmann TT. Monitoring of phosphorus bioavailability in water by an immobilized luminescent cyanobacterial reporter strain. Biosens Bioelectron. 2001;16:811-8.

112. Selifonova O, Burlage R, Barkay T. Bioluminescent sensors for detection of bioavailable $\mathrm{Hg}(\mathrm{II})$ in the environment. Appl Environ Microb. 1993;59:3038-90.

113. Semple KT, Doick KJ, Jones KC, Burauel P, Craven A, Harms H. Defining bioavailability and bioaccessibility of contaminated soil and sediment is complicated. Environ Sci Technol. 2004;38:228A-31A.

114. Shemer B, Palevsky N, Yagur-Kroll S, Belkin S. Genetically engineered microorganisms for the detection of explosives' residues. Front Microbiol. 2015;6:1175.

115. Shi Y, Lu Y, Meng F, Guo F, Zheng X. Occurrence of organic chlorinated pesticides and their ecological effects on soil protozoa in the agricultural soils of North Western Beijing, China. Ecotox Environ Safe. 2013;92:123-8.

116. Shin D, Moon HS, Lin CC, Barkay T, Nam K. Use of reporter-gene based bacteria to quantify phenanthrene biodegradation and toxicity in soil. Environ Pollut. 2011;159:509-14.

117. Smith LM, Tola E, deBoer P, O'Gara F. Signalling by the fungus Pythium ultimum represses expression of two ribosomal RNA operons with key roles in the rhizosphere ecology of Pseudomonas fluorescens F113. Environ Microbiol. 1999;1:495-502.

118. Standing D, Meharg AA, Killham K. A tripartite microbial reporter gene system for real-time assays of soil nutrient status. FEMS Microbiol Lett. 2003;220:35-9.

119. Steidle A, Sigl K, Schuhegger R, Ihring A, Schmid M, Gantner S, Stoffels M, Riedel K, Givskov M, Hartmann A, Langebartels C, Eberl L. Visualization of $\mathrm{N}$-acylhomoserine lactone-mediated cell-cell communication between bacteria colonizing the tomato rhizosphere. Appl Environ Microb. 2001;67:5761-70.

120. Stiner $\mathrm{L}$, Halvorsen LJ. Development and characterization of a green fluorescent protein-based bacterial biosensor for bioavailable toluene and related compounds. Appl Environ Microb. 2002;68:1962-71.

121. Swenson TL, Jenkins S, Bowen BP, Northen TR. Untargeted soil metabolomics methods for analysis of extractable organic matter. Soil Biol Biochem. 2015;80:189-98.

122. Symons BD, Sims RC. Assessing detoxification of a complex hazardous waste, using the Microtox ${ }^{\text {TM }}$ bioassay. Arch Environ Con Tox. 1988;17:497-505.

123. Tauriainen S, Karp M, Chang W, Virta M. Luminescent bacterial sensor for cadmium and lead. Biosens Bioelectron. 1998;13:931-8.

124. Thiele-Bruhn S. Pharmaceutical antibiotic compounds in soils-a review. J Plant Nutr Soil Sc. 2003;116:145-67.

125. Tom-Petersen A, Hosbond C, Nybroe $\varnothing$. Identification of copperinduced genes in Pseudomonas fluorescens and use of a reporter strain to monitor bioavailable copper in soil. FEMS Microbiol Ecol. 2001;38:59-67.

126. Torsvik V, Øvreås L, Thingstad TF. Prokaryotic diversity — magnitude, dynamics and controlling factors. Science. 2002;296:1064-6.

127. Trevisan S, Francioso O, Quaggiotti S, Nardi S. Humic substances biological activity at the plant-soil interface: from environmental aspects to molecular factors. Plant Signal Behav. 2010;5:635-43.

128. Urban A, Eckermann S, Fast B, Metzger S, Gehling M, Ziegelbauer K, Rübsamen-Waigmann H, Freiberg C. Novel whole-cell antibiotic biosensors for compound discovery. Appl Environ Microbiol. 2007;73:6436-43.

129. van der Lelie $D$, Regniers $L$, Borremans B, Provoost A, Verschaeve $L$. The VITOTOX ${ }^{\circledR}$ test, an SOS bioluminescence Salmonella typhimurium test to measure genotoxicity kinetics. Mutat Res. 1997;389:279-90.

130. van der Meer JR, Tropel D, Jaspers M. Illuminating the detection chain of bacterial bioreporters. Environ Microbiol. 2004;6:1005-20.

131. van der Meer JR, Belkin S. Where microbiology meets microengineering: design and applications of reporter bacteria. Nat Rev Microbiol. 2010;8:511-22.

132. van Dyk TK, Majarian WR, Konstantinov KB, Young RM, Dhurjati PS, LaRossa RA. Rapid and sensitive pollutant detection by induction of heat shock gene-bioluminescence gene fusions. Appl Environ Microb. 1994;60:1414-20.

133. van DykTK, DeRose EJ, Gonye GE. LuxArray, a high-density, genome wide transcription analysis of Escherichia coli using bioluminescent reporter strains. J Bacteriol. 2001;183:5496-505.

134. Verma N, Bhardwaj A. Biosensor technology for pesticides-a review. Appl Biochem Biotech. 2015;175:3093-119.

135. Virta M, Lampinen J, Karp M. A luminescence-based mercury biosensor. Anal Chem. 1995;34:667-9.

136. Vollmer AC, Belkin S, Smulski DR, van DykTK, LaRossa RA. Detection of DNA damage by use of Escherichia coli carrying recA': lux, uvrA':lux or alkA': Iux reporter plasmids. Appl Environ Microb. 1997;63:2566-71.

137. Wang X, Yu X, Bartha R. Effect of bioremediation on polycyclic aromatic hydrocarbon residues in soil. Environ Sci Technol. 1990;24:1086-9.

138. Weitz HJ, Ritchie JM, Bailey DA, Horsburgh AM, Killham K, Glover LA. Construction of a modified mini-Tn5 luxCDABE transposon for the development of bacterial biosensors for ecotoxicity testing. FEMS Microbiol Lett. 2001;197:159-65.

139. Weitz HJ, Campbell CD, Killham K. Development of a novel, bioluminescence-based, fungal bioassay for toxicity testing. Environ Microbiol. 2002;4:422-9.

140. Willardson BM, Wilkins JF, Rand TA, Schupp JM, Hill KK, Keim P, Jackson PJ. Development and testing of a bacterial biosensor for toluene-based environmental contaminants. App Environ Microbiol. 1998;64:1006-12. 
141. Yeomans CV, Porteous F, Patterson E, Meharg AA, Killham K. Assessment of lux-marked Pseudomonas £uorescens for reporting on organic carbon compounds. FEMS Microbiol Lett. 1999;179:79-83.

142. Yolcubal I, Piatt JJ, Pierce SA, Brusseau ML, Maier RM. Fiber optic detection of in situ lux reporter gene activity in porous media: system design and performance. Anal Chim Acta. 2000;422:121-30.

143. Zamboni A, Astolfi S, Zuchi S, Pii Y, Guardini K, Tononi P, Varanini Z. Nitrate induction triggers different transcriptional changes in a high and a low nitrogen use efficiency maize inbred line. J Integr Plant Biol. 2014;56:1080-94.
144. Zhang ZG, Pierson LS. A second quorum sensing system regulates cell surface properties but not phenazine ic production in Pseudomonas aureofaciens. App Environ Microb. 2001;67:4305-15.

\section{Submit your manuscript to a SpringerOpen ${ }^{\circ}$ journal and benefit from:}

- Convenient online submission

- Rigorous peer review

- Immediate publication on acceptance

- Open access: articles freely available online

- High visibility within the field

- Retaining the copyright to your article

Submit your next manuscript at $>$ springeropen.com 